\title{
Resenha 3
}

\section{A NATUREZA SOCIAL DAS FINANÇAS -}

mundialização, governança corporativa e fundos de pensão

em um contexto do novo espírito do capitalismo.

Marcio Rogério Silva* e Wellington A. Desiderio*

O livro A natureza social das finanças: fundos de pensão, sindicalistas e recomposição das elites, organizado por Maria A. Chaves Jardim, é uma coletânea de artigos pautados em análises aludidas aos fenômenos ocorridos no capitalismo recente. O livro versa sobre a mundialização das finanças e sobre os atores que exercem papéis sociais-chave para a atual configuração do capitalismo. Dessa forma, elites, fundos de pensão e sindicalistas estão no cerne das atenções. Os artigos possuem natureza descritiva e analítica, e seus ferramentais metodológicos são vindouros da sociologia. Logo, as variáveis sociais são consideradas cruciais para entender o funcionamento da economia. Os autores são pesquisadores brasileiros e franceses.

\section{A MUNDIALIZAÇÃO FINANCEIRA E OS TEMPOS DE CRISE}

Os artigos de Jean-Marc Siroen - Uma mundialização em crise - e Frédéric Lebaron - Mundialização financeira ou imposição do modelo norte-americano? - analisam os momentos de crise financeira evidenciados nos últimos anos. Siroen indica em seu texto as inconsistências entre o que a globalização prega como ideal e o que tem ocorrido na realidade. Para o autor, a crise atual teria nascido de uma regulamentação insuficiente, contudo, chama a atenção para a eficácia de a regulamentação não poder ser superestimada. Além disso, ele cita a falta de uma governança mundial, que está focada na atuação pontual de bancos centrais, como também diz que o FMI deveria cumprir um papel na busca do equilíbrio

Recebido para publicação em 8/8/2012.

Aceito para publicação em 10/12/2012.

* Mestrandos em Engenharia de Produção pela UFSCar. 
compatível com o crescimento econômico, coordenando as políticas econômicas e criando sanções aos desequilíbrios. Por outro lado, o autor comenta que a globalização não apagou os regulamentos nacionais, e, como a exemplo dos fundos de pensão, cada país tem instituições diferentes. Em suma, segundo o autor, como não há vislumbre de mudanças pós-crise, uma vez que o aumento de liquidez no mercado financeiro gera uma nova euforia e novas bolhas, sua última pergunta é: “quando será a próxima crise?”.

Já o texto de Lebaron trata a crise do modelo financeiro norte-americano indicando um aparente paradoxo. O sistema financeiro americano apresenta cada vez mais fragilidades, com os Estados Unidos apresentando déficits financeiros. Contudo, eles permanecem como credores no plano simbólico, sobretudo na teoria financeira e, em um âmbito maior, na teoria econômica, exportando seu modelo nacional. Esse modelo, segundo o autor, é um conjunto de características institucionais e culturais, bem como as propriamente econômicas, tendo sempre ligação com as instituições públicas e os atores públicos.

Lebaron também aponta que o poder público exerce função limitada de regulação, sendo o Banco Central dos Estados Unidos responsável por intervir em crises, tidas como naturais nas finanças do mercado, encaradas dessa maneira pelo menos até a crise dos subprime. Finalmente, Lebaron questiona os limites entre o mundo percebido e o mundo real, considerando a crise de crenças gerada pela crise do mercado financeiro, notadamente do subprime, necessitando de uma conversão de pontos de vista, o que ele chama de revolução simbólica.

Somando a esse debate, Roberto Grün - com o artigo A evolução da governança corporativa no Brasil: inovações financeiras, convergência das elites e estabilização do sistema - analisa o contexto internacional da criação, importação e difusão de mudanças organizacionais e novas institucionalidades. $\mathrm{O}$ autor parte do modelo específico de governança corporativa - principal ferramenta de gestão do modelo financeiro - e sua concepção dentro do contexto nacional norte-americano e das particularidades que ela adquire no Brasil.

Nesse sentido, o autor centra a discussão de que a governança corporativa ganhou no Brasil novas feições, em que os contextos da crise econômica que ocorreu após o milagre econômico criaram um ambiente propício a fórmulas de salvação da economia nacional, que passaram pela qualidade do modelo japonês, criando um ambiente para consultores e agentes que importavam ideias para o setor governamental. A recuperação do prestígio perdido pelos financistas viria com a governança corporativa, por um lado, estabelecendo um quadro que aumentasse a confiança dos investidores e, por outro lado, que trouxesse segurança jurídica, dando margem de participação a financistas e profissionais do direito. 
Outro ponto apontado pelo autor se refere à peculiaridade da governança corporativa no Brasil, pois ela agrega a necessidade de responsabilidade social das empresas, prevenindo-as de perdas advindas de riscos morais. Além disso, ela foi capaz de realizar uma convergência entre poder sindical e empresarial, fundos de pensão e investidores tradicionais, em um contexto em que os trabalhadores se tornaram pouco propensos a apostar suas fichas na contestação sindical. Dessa maneira, a extensão dos circuitos de legitimação diminuiu os graus de liberdade de ambos os grupos, e ambos têm de considerar a aceitação de pré-julgados financeiros e exigências sociais, aumentando a estabilidade simbólica do capitalismo brasileiro.

\section{FUNDOS DE PENSÃO E SUA RELAÇÃO COM AS ELITES EMPRESARIAIS, SINDICAIS E COM OS ASSALARIADOS}

Anne Catherine Wagner, em seu artigo Dirigentes e sindicalistas na mundialização: reconfigurações das relações sociais e emergência de novos atores, analisa os acessos aos espaços sociais e institucionais internacionais, os novos atores que emergem nesse processo e como eles se situam em relação aos outros. Para isso, a autora estuda o processo de internacionalização dos altos cargos de líderes de empresa e dos sindicalistas, classificando o capital cultural como uma nova espécie de capital que mistura as dimensões econômicas, culturais e simbólicas, fundando novas posições sociais e novas posições econômicas.

A autora mostra que os dirigentes econômicos que percorreram as mesmas business schools, unidos pelos mesmos interesses e pela mesma cultura de negócios, falando a mesma língua, formaram redes internacionais que seguem harmoniosamente a globalização da produção, ao contrário das confederações sindicais, construídas sob histórias nacionais distintas, com relações profissionais heterogêneas, separadas por barreiras linguísticas e geográficas. Contudo, no meio sindical também desenvolveram-se carreiras internacionais, em que os experts reúnem conhecimento técnico e habilidade em dialogar com dirigentes e membros das classes superiores, podendo fragilizar sua posição em sua confederação, pois entram em contradição com outras fontes de legitimidade sindical.

Já Sabine Montagne, no artigo O truste ou o impensável poder da finança, toma como base o direito, na articulação entre o assalariado e a finança, nos fundos de pensão, passando por definições em torno do benefício definido e da contribuição definida. Para explicar essa relação, a autora passa pelo conceito de truste, que define que os assalariados são colocados em uma posição estruturalmente passiva tanto com relação ao empregador como com relação ao intermediário financeiro. A autora aponta que, na medida em que a aposentadoria é um elemento da relação 
salarial, os fundos de pensão se revelam em uma lógica de relação de forças (fordista), em que os privilégios do truste são transferidos para outras entidades econômicas, concluindo que ocorreu uma transferência a uma poupança inteiramente econômica, sem a proteção comparável ao truste, o qual tinha privilégios por conta da proteção às aposentadorias.

No artigo de Bruno Théret, $O$ debate crítico francês sobre os fundos de pensão na virada do terceiro milênio, o autor relata um debate, na virada de 2000, que contrapôs os partidários da repartição e da capitalização, afirmando que os argumentos desses segundos se tornaram cada vez mais frágeis. No artigo, há um argumento sobre a existência de um debate político-científico liderado pelos economistas, com considerações em termos de eficiência, por meio de ferramentas estatísticas. Contudo, o autor chama a atenção para o fato de que a mudança institucional não é regida necessariamente pela racionalidade econômica, bem como retrata que há uma disputa de crenças de ambos os lados, sem dúvida, em uma abordagem inovadora de Théret.

Por fim, o capítulo Governo Lula, sindicatos e fundos de pensão: moralização do capitalismo?, de Maria Chaves Jardim, apresenta um estudo em torno da interação de sindicalistas, ex-sindicalistas, empresários dos fundos de pensão e governo federal, debatendo sobre a cumplicidade e os interesses desses agentes, apresentando como afirmação principal a convergência ou recomposição de elites em torno dos fundos de pensão.

A autora inova ao fugir de leituras fundamentadas em interesses estritamente econômicos dos fundos e de leituras jornalísticas de venda dos sindicatos ao mercado, uma vez que essa nova atuação sindical em torno dos fundos de pensão se julga com legitimidade moral para defender os interesses dos trabalhadores, passando a incorporar preocupações econômicas em seu discurso, ao passo que o mercado financeiro passou a incorporar conceitos como ética, democracia, inclusão social e solidariedade. Há, aqui, uma convergência ou recomposição de elites.

Com um interessante prefácio redigido pela professora Nadya Araujo Guimarães, esse livro deve ser uma referência para aqueles que se dedicam à compreensão do espírito do novo capitalismo, que traz em seu âmago as finanças, a remodelação das elites e os fundos de pensão.

\section{REFERÊNCIAS BIBLIOGRÁFICAS}

JARDIM, Maria Aparecida Chaves (Org.) A natureza social das finanças: fundos de pensão, sindicalistas e recomposição das elites. Bauru: EDUSC, 2011. 